\title{
Enhancing EFL Learners' Writing Skill via Journal Writing
}

\author{
Hanif Maulaniam Sholah \\ IAI Al-Qolam \\ (hanif@alqolam.ac.id)
}

Approved: 2020-01-22

\author{
Key Words: \\ English Writing \\ EFL Learners \\ Journal Writing
}

ABSTRACT

English writing, for a number of EFL learners, appears to be challenging. Let alone, this language should be mastered by every learner since English is mean of communication between nation and nation, country and country all over the world. This paper aims to investigate whether learners can improve their writing ability and grow out of the writing difficulties by engaging in journal writing activity. 60 second-year students from the two writing classes are involved. One treated as the experimental group (EG) and the other as the control group (CG), at the Faculty of English Department Education of the IAI Al-Qolam Gondanglegi were invited to participate in the study, whose findings shows the benefits of journal writing as an extensive activity to enhance learners' writing motivation and foster their writing skill as well as to build a close interactive communication between teachers and learners.

\section{Introduction}

Language is an important tool in communication in society. states that language is a mean of communication to interact one another in the society (Larsen-Freeman). It has a function as a tool to communicate with other people in the environment. People realize that without a language, they cannot interact with one another. It can be a bridge to each other and to live in different culture. By using language, one can obtain information and knowledge, as well as express feeling. Recently many people learn the international language; it is English.

Hanif Maulaniam Sholah

Enhancing EFL Learners' Writing Skill via Journal Writing
(96)

ALSUNA Vol. 2 (2), 2019

http://e-journal.ikhac.ac.id/index.php/alsuna https://doi.org/10.31538/alsuna 
English as an international language is used to communicate in almost all of the world. According to (Harmer), English is used widely for communication between people who do not have English as the first language or even a second language. Thus, many people try to master English to compete in the globalization era. Accordingly, English is taught as the first international language and an important subject in Indonesia from elementary to university level. The students get English skills which include listening, speaking, reading and writing.

There are a number of ways that can be used to learn English. One of the ways is through education. Since English might be a foreign language for some countries, education is considered the best way to learn English. In Indonesia, English is learnt as a foreign language and as one of compulsory subjects that should be learnt by students especially in the secondary school level, such as in junior and senior high school. English is also taught in tertiary level such as in Universities and is a compulsory subject across study programs. A study by(Amalia) related to developing English textbook material in Islamic Primary Education Program corroborates the demands of English to be mastered by student-teachers (pre-service teachers).

Out of the four fundamental language skills in the language learning process, “writing component is frequently accepted as being the last language skill to be acquired for native speakers of the language as well as for foreign/second language learners." (Hamp-Lyons and Heasly) whereas, EFL learners' success in English writing brings them benefits not only in their English learning but also in their life-long careers as Glazier (1994: 3) contends, "Being able to write in English is essential in college, and it probably will be an asset in your career." For a number of EFL learners, English writing appears to be challenging (Harmer). In terms of fluency, (Nunan) maintains that producing a coherent, cohesive and fluent writing activity is likely the most difficult thing in language

Hanif Maulaniam Sholah

Enhancing EFL Learners' Writing Skill via Journal Writing
(97)

http://e-journal.ikhac.ac.id/index.php/alsuna https://doi.org/10.31538/alsuna 
since writer should be able to make the reader comprehend what has been written without asking for clarification or relying on the writer's tone of voice or expression.

Writing is an activity which require the ability to master grammar vocabulary, and accuracy in using the language. This is because writing requires a high level of learning. Then, to write well, the students are expected to write the ideas in writing as a means of communication not only to express the ideas but also to use the full sheet energy to complete process. Writing is a skill that is taught integratedly but many students still have problems such as lack of vocabularies, develop ideas, and lack of grammar (Fegerson and Nickerson).

The result of researcher's interview to Some English teachers in some private school in Malang, they said that the students ${ }^{\text {ee }}$ motivation to write was low. Some students were extremely unconfident and reluctant to write due to some reasons. The main reason was that they thought they had nothing to write and when they had already got the ideas of what to write about, the lacks of vocabulary, grammar, and sentence organization made their ideas could not be properly conveyed.

Therefore, most students seemed to be frustrating when they have to write about something. Most students even judged themselves that they were not good at writing. They thought that they do not have talents in writing. Actually, those kinds of thoughts often burden themselves and influence their attitudes towards writing. So, the result is that they try to avoid writing, and when they do writing, they do not give their best.

It seems that the nature of writing itself is not interesting enough to motivate students to practice regularly and more oftenly (Hedge). For many English learners, nothing more motivated activity than doing writing task and considering that they are under the eyes of the teacher who will correct their work. As (Hamp-Lyons and Heasly) states: a number of people write spontaneously and feel comfortable with a formal writing

Hanif Maulaniam Sholah

Enhancing EFL Learners' Writing Skill via Journal Writing
(98)

\footnotetext{
http://e-journal.ikhac.ac.id/index.php/alsuna https://doi.org/10.31538/alsuna
} 
task if it is intended someone they prefer to. When the "someone " is the teacher, whose eyes may be critical, and who probably assign an individual assessment to the written product, most people feel uncomfortable.

Few students not purely feel tired in writing but find themselves like encountering hide-and-seek game with ideas as well since they are obliged to write about what is directed by their teacher rather than about what come up in their mind which is more relevance to them, as (Byrne) states, "Being at a loss for ideas is a familiar experience to most of us when we are obliged to write" and (Tho) contend, "Non-native writers may not have enough ideas to write down or, even worse, they have nothing to say."

Beside the lack of motivation, time pressure also hinders learners' writing performance. In the EFL classroom, students tend to be compelled to perform their writing tasks within a certain length of time. Thus, a number of students occasionally cannot accomplish their work since it is in under pressure atmosphere. (Weir) gives an understanding view: Time pressure is often an unrealistic situation for extended writing and writing timed essays is not normally done in the real life. For most people the writing process takes longer time and may involve several tasks before they produced finish version. In this case, (Chanderasegaran) pronounces, "A problem to be expected in the writing classroom is that some students take much longer than others to write the required parts of the essay. Many never finish their writing in class." This study tried to investigate whether or not learners can grow out of the difficulties mentioned above by engaging in journal writing based on (Lagan) elaboration: Because writing is a skill, it makes sense that the more you practice writing, the better you will write. One excellent way to get practice writing, even before you begin outlining essays, is to keep a daily writing or almost daily journal. This study is aimed to know the effectiveness of journal writing to improve students writing skill.

Hanif Maulaniam Sholah

Enhancing EFL Learners' Writing Skill via Journal Writing
(99)

http://e-journal.ikhac.ac.id/index.php/alsuna https://doi.org/10.31538/alsuna 


\section{Research Problem}

Therefore, guided from the background above, this research has two big questions to figure out: Do students who learn writing through journal writing achieve better score? Can journal writing generate students' writing motivation?

\section{Review related literature on journal writing}

Classroom writing is an essential academic activity. Furthermore, writing outside the classroom can be a useful tool to enhance writing skill (Chanderasegaran). Using media is considered as tools that can give contribution to the teaching and learning process. It can attract students' interest, bring positive attitude and make the teaching learning run well (Zuana). The media to practice writing at home is keeping journals which are diaries in which writers keep any ideas, opinions, stories and description of daily life. "Journals writing help writers to develop their creativity" (Spaventa). Journal writing helps learners write better and better day by day since it provides learners with more times or opportunities to write freely about what they feel and they wish to write whenever it is. (Hamp-Lyons and Heasly) propose: "The most obvious way you can help yourself become a good writer is by writing. We strongly suggest that in addition to completing the tasks, you also keep your own personal journal. Buy yourself a notebook, and try to write down some ideas every day, in English, about anything that interests you. You will surprise yourself by producing pages and pages of writing.

By keeping journals, students can record their personal or life activities. Students find journal writing an enjoyable experience since the primary aim of keeping a journal is "to encourage students to become involved and interested in writing" (White and Arndt) without concerning much about errors and time pressure (Spaventa). The benefits of

Hanif Maulaniam Sholah

Enhancing EFL Learners' Writing Skill via Journal Writing
(100)

http://e-journal.ikhac.ac.id/index.php/alsuna https://doi.org/10.31538/alsuna 
journal writing are elaborated in (White and Arndt) discussion: This technique has been found to be an effective and productive tools of making interest in writing, which, at the same time, develops fluency of expression. It also helps students to become aware of why they wish to express their ideas in writing activity not only as a means of personal expression, but also as a dialogue in written language to communicate with the reader. Additional benefit is that "journal writing provides students with good opportunities to improve their writing skills individually and good chances to record their thoughts and feelings" (Ngoh). There are many goodness for keeping a journal. In addition to any conversation that takes place between you and your instructor: when you have finished the course, you will have a record of what you read, what you experienced and what you thought about during that time (Spaventa). ta In convincing learners of the goodness of journal writing, (Lagan) argues: Writing a journal will help you develop the habit of thinking on paper and show you how ideas can be discovered in the process of writing. A journal can make writing a familiar part of your life and can serve as a continuing source of ideas for writing activity. Also it can makes students to Consider journal writing as a way to develop the habit of expressing one's thoughts into paper with looking upon journal writing as a way to develop accuracy on writing. (Lagan) shows the correlation between clear thinking and accuracy by quoting his ex-teacher's words "If you don't think clearly, you won't write clearly." It cannot definitely to be expected that the first pieces of journal written by mostly student are coherence, systematic and logical; however, in the long way, time by time, with the teacher's facilitation, journal writing can eventually lead to disciplined thinking and increase accuracy.

Moreover, as "journal writing can show you how ideas can be discovered in the process of writing" (Lagan), it obviously helps decrease the chaotic situation in which students often find themselves lack of ideas, and thus can encourage fluency. In several

Hanif Maulaniam Sholah

Enhancing EFL Learners' Writing Skill via Journal Writing
(101)

http://e-journal.ikhac.ac.id/index.php/alsuna https://doi.org/10.31538/alsuna 
researcher's view, journal writing is considered to be one type of creative writing that can help students brainstorm ideas and write more competently and accurately as (Tin) proposes: “Creative writing activities can change students' perceptions not merely on writing but also on themselves and the world they live in, lower their anxiety, and develop their writing proficiency, accuracy and personalities." Journal writing can also give another benefit that infrequently done in classroom writing. While in classroom writing tasks tends to make students nervous, journal writing let the students to write out of teacher's watch, so the students can write more enjoyable because they don't feel afraid or reluctant in the process of writing. A supportive learning atmosphere will thereby be created along with a high learning motivation, which students more and more integrate into their formal writing (Ngoh). The question of correction in journal writing, however, remains vaguely in this case. It is discouraging if the teacher acts towards the students' writing as a source of errors to be corrected and revised. On the contrary, how can the students know what aspect of language in their writing they should improve without error diagnosis or teacher's correction and remedial feedback? This issue is discussed by (White and Arndt) who suggest: "Because writers have to achieve a high degree of autonomy and self-sufficiency, it is very important to promote ways of self-correcting from an early stage. Inevitably, we teachers will want to draw attention to language items which seem to be important to us as readers. Several points should be kept in mind when we do so: - Concentrate on language errors which have global rather than local effects. This means attending to formal language errors which interfere with meaning over a broader period than the individual clause or sentence. - Do not attempt to cover too many repairs. It is quite impossible for learners to cope with too many problems simultaneously."

Hanif Maulaniam Sholah

Enhancing EFL Learners' Writing Skill via Journal Writing
(102)

http://e-journal.ikhac.ac.id/index.php/alsuna https://doi.org/10.31538/alsuna 


\section{Research Method}

This research belongs to quantitative and qualitative research since the data is dealing with descriptive and numerical data. This research is aimed to prove whether journal writing can enhance students writing skill or not using comparison of two groups (experimental group and control group). So, the research method used to draw conclusion is experimental research design .The method of this research is explained through three parts. They are participants, instruments and construction of items. The participants is explained first since it is the subject of the research. Then, followed by instrument to know how the subject response is measured to achieve finding which come to the conclusion. The third is construction of items or questionnaires to know the process of questionnaires constructed.

\section{Participants}

This study was carried out in Al-Munawwariyyah Senior High School Malang in September 2017. A quantitative and qualitative (mixed method) survey study exploring the effectiveness of journal writing on improving writing skill are used to identify the issues which are concern to the usage of journal writing for learning which is still vague its effectiveness. Among 150 students population, sixty students are taken as participants in this study. Those two classes are from class XI IPA 1 and XI IPA 2. The number of students on each classes are 30 students. The average age of the participants are 17 and 18. The reason for choosing those participants is because those two classes are considered having equal ability known from their pretest and writing activity record got from the English teacher.

One second-year class (XI IPA 1) which have 30 students was treated as the experimental group (EG), and the other (XI IPA 2) which also have 30 students was treated as the control group (CG). The students in the experimental group were immersed in

Hanif Maulaniam Sholah

Enhancing EFL Learners' Writing Skill via Journal Writing

\footnotetext{
http://e-journal.ikhac.ac.id/index.php/alsuna https://doi.org/10.31538/alsuna
} 
writing journal entries outside the classroom beside they also have to accomplish classroom writing activities while take-home written assignments were required to accomplish by the students in control group beside they have to follow classroom writing activity like what experimental group do.

\section{Instrumentation and procedure}

Pretest and posttest in the form of essay writing were employed as instruments to measure students' writing proficiency level in terms of fluency and accuracy. Accuracy is the ability to avoid error in writing performance. And fluency "concerns the learner's capacity to produce language in real time without undue pausing or hesitation. It is likely to rely upon more lexicalized modes of communication as the pressures of real time speech production are met only by avoiding excessive rule-based computation"(Skehan).

The first writing mastery level of the whole population of second-year students was investigated by the pretest. The material of pretest was recount text with 45 minutes duration for each group. The result of pretest are analyzed and used to determine experimental group and control group from scores which have virtually similar writing competence level. The materials used for conducting test as well as for teaching in giving treatment for both experimental and control group were recount text for senior high school grade XI. Students on experimental group were encouraged to write journal entries or diary related to their daily life as much and as regularly as they could in their notebooks during the thirteen weeks between the pretest and posttest. This experimental group activity in writing journal diary took a place on midterm of July to October 2017. They can write about their experience in that day and what was happening to them or people surround them in their journal entry. The researcher also kept a journal, whose purpose was to record any change in writing fluency and accuracy as well as writing motivation

Hanif Maulaniam Sholah

Enhancing EFL Learners' Writing Skill via Journal Writing

$$
\begin{array}{r}
\text { ALSUNA Vol. 2 (2), } 2019 \\
\hline \text { http://e-journal.ikhac.ac.id/index.php/alsuna } \\
\text { https://doi.org/10.31538/alsuna }
\end{array}
$$


made by the students during the process of research. While for the control group, they are doing writing activity in the classroom, working on some task on their textbook and having discussion with their teacher and their friend to finish their task in the classroom. Since writing activity in the classroom has limited time, students on control group also given homework to do some writing task on their textbook to make sure that they also study writing at home. On the other hand, control group have to do some writing exercise at home like filling the blank on jumble paragraph and incomplete sentence, describing picture, writing some sentences following the guided questions and arranging some sentences into good paragraph while experimental group are freely given opportunity to write anything they want related to what was happening on their days. After the process of treatment given as long as thirteen weeks, the students in both experimental group and control group took the post-test, whose purpose was to assess the impact of journal writing on the quality of the students' in-class and take-home writing tasks.

\section{Finding and Discussion}

Impact of journal writing practice on learners' writing fluency, writing fluency in this research was measured through the writing speed. On the other hand, the number of words produced within limited length of time was counted to determine the level of students fluency. The more words students produce, the better fluency level they can get.

As shown in Table 1, the average number of words generated by the students in the control group for their 45-minute pretest was 195.21, and that generated by the students in the experimental group was 194.20. Thus, the difference in the average number of words generated by the students between the control group and the experimental group was on the point 1.01 words higher for control group. It can be

Hanif Maulaniam Sholah

Enhancing EFL Learners' Writing Skill via Journal Writing
(105)

http://e-journal.ikhac.ac.id/index.php/alsuna https://doi.org/10.31538/alsuna 
implied that before experimental group was involved into journal writing, the writing speed of the students in both groups was virtually equal.

Further, after the students practice journal writing for thirteen-week, they are involved into posttest whose the result indicated different average number of words produced by the students between the two groups. The result of posttest in control group showed that the average number of words produced by control group in the posttest was 203.11 words. It means that the disparity in the average number of words in the control group between the posttest and the pretest was 7.90 words $3.89 \%$ improvement of the average number of words per essay produced by control group in Pretest) whereas the students in the experimental group showed the number of average of words produced in posttest was 213 implying that the disparity between the posttest and the pretest was 18.80 words $(9.80 \%$ improvement of the average number of words produced by experimental group in posttest). From the data, it can be implied that the writing progress of the students in the experimental group improved to a higher extent than those in the control group. In addition, the students in the experimental group performed the better improvement in the extent of writing task completion than those in the control group.

Impact of journal writing practice on learners' writing accuracy, according to Table 2, it can be seen that the average number of mistakes left in the pretest by the students in the control group was 22.56 and that by the students in the experimental group was 23.00. Therefore, the different in the average number of mistakes left by the students between both of groups was 1.56 mistakes, implying that before they come into journal writing activity, the writing accuracy level of the students are not substantially different. The thirteen-week practice of journal writing, however, brought about the different result on the average number of mistakes made by the students between the two groups. The average number of mistakes left by the students in the control group fell by 15.88 mistakes

Hanif Maulaniam Sholah

Enhancing EFL Learners' Writing Skill via Journal Writing
(106)

http://e-journal.ikhac.ac.id/index.php/alsuna https://doi.org/10.31538/alsuna 
(30.20\% improvement) in the posttest compared with the pretest, whereas that in the experimental group fell by 8.12 mistakes (60.80\% improvement) in the posttest compared with the pretest, denoting that the students in the experimental group demonstrated the better progress in the level of writing accuracy than those in the control group.

Impact of journal writing practice on learners' writing scores, the data from Table 3 shows that an insignificant disparity (0.10) was found between the experimental group and the control group in terms of average pretest score. The average pretest score achieved by the students in the control group was 6.30 points and that by the students in the experimental group was 6.20 points. Nevertheless, the average posttest scores earned by the students in both groups significantly diverged. The average score of posttest achieved by students in control group was 6.76, whereas the average score of posttest achieved by students in experimental group was 7.56, which implies that the average posttest score gained by the students in the control group increased by 0.46 points $(7.30 \%)$ compared to the average pretest score, while that in the experimental group increased by 1.36 points $(21.9 \%)$ compared to the average pretest score.

Impact of journal writing practice on learners' writing motivation, based on Table 4, journal writing practice generate the EG students' preference towards this activity as well as their awareness of its worth in their writing learning. It can be seen from the response of the question number 1 which asks about their preference about journal writing. The result shows that 21 positive responses (70\%) to question 1 and 22 positive responses (74\%) to question 2. It can be implied that according to experimental group students, mostly they stated that journal writing can be their preference activity and useful for them to improve their writing skill. A high response rate regarding as journal writing regularity in the EG students was found through the data that 11 out of 30 students (36\%) in the experimental group stated to have spent roughly an hour writing journal diary in a day,

Hanif Maulaniam Sholah

Enhancing EFL Learners' Writing Skill via Journal Writing

$$
\begin{array}{r}
\text { ALSUNA Vol. 2 (2), } 2019 \\
\hline \text { http://e-journal.ikhac.ac.id/index.php/alsuna } \\
\text { https://doi.org/10.31538/alsuna }
\end{array}
$$


and 13 out of 30 students (44\%) claimed to have spent more or less half an hour writing journal diary per day, and then 6 students out of 30 students $(6 \%)$ pronounced to have spent less than 25 minutes writing journal diary daily.

However, the number of students who write journal diary directly into English from their mind is only on the small number, 6 students out of 30 students $(20 \%)$. It means that a majority of the EG students, 24 students out of 30 students (80\%) still keep the habit of generating ideas in their mother tongue, then translate them into the target language, English language.

Interestingly, a high rate of motivation in journal writing was found to have been built in the EG students since 25 out of 30 (83\%) the students in the experimental group stated to keep continuing journal writing activity after this writing course.

Impact of journal writing practice on learners' achievement and motivation recorded through observations and interviews, the change in the EG students' achievement and writing motivation was also recorded via observations of their journal diaries activity and interviews related to students progress for their journal diaries activity. Observations encountered that it took the EG students more or less three weeks to get accustomed to journal writing activity. The participants of journal writing and interview are encoded with P01, P02, P03 and so on. Apparently, most of them produced short sentences in simple language to expose their feelings or to reflect on certain events of their day. Some students even left blanks or used Indonesian language to fill in the vocabulary gaps in their journal sheet. One student began her journal writing activity with the sentence:

I never write journal. I don't know I can write journal or not, but Mr. Hanif forced me to write journal to improving my writing skill and he will correct my mistakes. I'll try and I hope he will help me. (P01) (The erroneous parts were underlined by the researcher.)

Hanif Maulaniam Sholah

Enhancing EFL Learners' Writing Skill via Journal Writing
(108)

http://e-journal.ikhac.ac.id/index.php/alsuna https://doi.org/10.31538/alsuna 
Regarding at the departure of journal writing journey, another student wrote: Last time, I sometimes write diary in Indonesia. Now My teacher Mr. Hanif asked us to write journal in English. I think it is difficult because I think I don't have many vocabularies and grammar to write diary. However, I will try because my teacher said that this activity is useful for my competence. I hope Mr. Hanif will keep my journal not to tell to my friends. (P02)

By the passing of days by days, the EG students grew more and more confident. Their writings become longer and longer. Although their errors still encountered in their journal entries, they have shown good progress. Somehow, they have learned from the errors they have made and they get many benefit from it.

After seven weeks of journal writing departure, a cooperative learning atmosphere appeared on the experimental group. Based on researcher's observation on the experimental group activity out of the classroom, it was often heard in the conversations at break time or after class such utterances as "Have you written your journal diary today?" and "What did you write about?". Those conversations shows a cooperative atmosphere. Furthermore, when the researcher asked voluntary to edit their friends journal diary outside the classroom, these voluntary students responded positively. They make a peer editing group to review and revise their friends work. In addition, students in this experimental group constructed blog to publish their journal diary. In this blog, they comments and share each other. The conversation on the blog that has been created by experimental group focused on the peer editing activity in writing journal diary.

This cooperative learning situation is very supportable for encouraging students to participate well in journal writing activity. A supported situation or cooperative learning atmosphere is not only happened between students and students but also

Hanif Maulaniam Sholah

Enhancing EFL Learners' Writing Skill via Journal Writing
(109)

http://e-journal.ikhac.ac.id/index.php/alsuna https://doi.org/10.31538/alsuna 
happened between teacher and students. This good relationship certainly can strengthen students' spirit and motivation in doing their journal writing activity as the task from the teacher. Through researcher's comments and responses to students writing, reflecting on journal writing, one student wrote:

Before I follow writing journal diary activity, I didn't know what was journal diary, but now I know what is journal diary. Journal diary is very interesting and I think, it is very useful for me because I can write everything I like in my notebooks. Mr Hanif always helps me to correct my mistakes. (P03)

To know the detail respond of Experimental Group students regarding with their interest in the activities, and if they needed any more help from the researcher, the interviews with EG subjects were occasionally held. The following dialogue is the recording of an interview between the researcher and a student in the experimental group (on October 21st, 2017).

The researcher recorded any document of each participant's progress in

Hanif Maulaniam Sholah

Enhancing EFL Learners' Writing Skill via

\section{THE INTERVIEWS WITH EG SUBJECTS}

Researcher: Do you like writing journals in English?

Student: Yes, I like.

Researcher: Why?

Student: Because I can learn and know many vocabularies.

Researcher: What else?

Student: And I can learn grammar, to improve my writing skill.

Researcher: Do you think that your friends like writing journals, too?

Student: Yes, I think they also like because many of them writes journal regularly and submit their journals to you at weekends.

Researcher: Do you get any difficulties in writing journals in English?

Student: Yes, I have many difficulties, such as words and structures. Sometimes I get trouble to express my ideas into English.

Researcher: Do you need any help?

Students: Yes, and I think you have helped me to correct my mistakes. So, I will try again and again to overcome my troubles in writing journal.

Researcher: How often do you write your journal diaries?

Student: About three to five times a week.

Researcher: How long do you spend writing a journal each time? Student: Sometimes fifteen minutes, sometimes almost an hour.

Researcher: Why don't you spend more time writing journal diaries?

Students: I can't because I have to study other lessons.

Researcher: Thank you very much for your answers.

Student: You're welcome sir. I hope that you will always help us to correct any mistakes we make.

Good bye, Sir.

Researcher: certainly. Good bye.

However, a number of students were not interested in journal writing. They told to the researcher their true feelings as stated on the following dialogue (recorded on October 22th, 2017):

Researcher: Do you like writing journals in English?

Students: Sorry. Not really sir.

Researcher: Why?

Student: I like to practice speaking English with my friends and listen to music because I think it is more enjoyable than writing journal diary.

Researcher: Do you think that your classmates like writing journals?

Student: I'm not sure.

Researcher: How often do you write your journal diary?

Student: I seldom write journal diary. Sometimes, once in a week when I have mood to write.

Researcher: How long do you spend writing journal diary each time?

Student: Around ten to fifteen minutes each time.

Researcher: I am sure that journal writing can help you a lot to improve your writing skill. You should try more and more to write journal diary.

Student: (Smile) Thank you sir.

Researcher: Thank you very much for your answers.

Student: you're welcome sir.

Researcher: Good bye. 
terms of accuracy, fluency, and the length of their journal diaries. The researcher collected new journal diaries from the students once a week and returned the previous diaries they have submitted one week before which is completed with encouraging comments and advice as feedback for students of experimental group.

By the end of the research, the students' journal diaries increased in the number of words. They also show the improvement in the term of interesting idea. Further, the number of errors decreased.

The following sentence is one of the journal diary submitted at the end of the course: I think the most difficult subject is mathematic and the busiest subject is English. English take my time much. I have to spend much of my time to do the task. May teacher asked us to write journal diary. Firstly, I don't really like writing because I cannot fine any good idea to write. However, my teacher said that we can write anything from our mind. We don't need to worry whether it is good idea or not. Just write anything we want to write. So, let me write about my day. I have thirteen subjects in one week and I have to learn them all. And the most spending time is doing the task from my English teacher. It seems annoyed. But, when I do it regularly, I realize something good for me. I feel my skill getting improved. I can write better than before. It is easier for me to express what in my mind into written language. I'm not afraid anymore about writing. Now, I have power of spirit to increase my English ability. I'm sure that my parents will be happy with me and my grandmothers must be proud of me. I have a plan to get scholarship. It demands me to study hard because scholarship is only for students who have good achievement. If I can get scholarship, I will buy present for my parents. I have a dream, after I graduate from this senior high school, I will continue my study into well known university. So, after I graduate from university, I will get the best job, and certainly I can earn much money. If it is possible, I will study in university while working to help my parents

Hanif Maulaniam Sholah

Enhancing EFL Learners' Writing Skill via Journal Writing
(111)

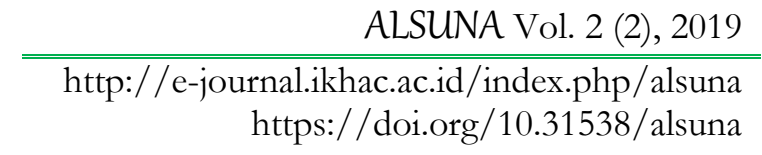


earning money. Through this activity, hehe I can utter my dream. I thank to my English teacher Mr Hanif. I like this activity and I hope you will not be tired and busy to correct our mistakes in writing English. We believe that Mr. Hanif will always do his best. (P04)

The positive change in writing motivation is also encountered in a student' final journal diary that follows: Writing journal in English is a very good way to improve my ability in English. Maybe, if long time before I used to write diary in English, perhaps my ability is better than now. Usually, I write diary but in Indonesia. I tell about my school, my girlfriend, and my friends and teacher. I express my feel through writing because I think, we express our thought more freely through a piece of paper. My Indonesian language is getting better. But, why don't I think that actually, I can use another language to write diary. I can do my hobby for pleasure because I like writing and I also can learn English if I write using English language. Recently, my English teacher asked us to write journal diary. I think it is not interesting since English is difficult lesson for me. But, Mr. Hanif convinced me that journal diary writing is very very helpful. Moreover, my hobby is writing. Then I try because he promised that he will correct my mistakes. A little by a little I learn writing English. Time by time, I learn much about English. And also my teacher, Mr. Hanif care about me and always revise my English writing. He is very patient. I begin enjoy this activity. I know that this activity for us is only research conducted by Mr. Hanif. But, since we have enjoyed it, we want that Mr. Hanif keep continuing this writing activity. We know that every at the end of the week, all students always submit their work. It means that all students in our class enjoy writing journal diary. We are sure if we keep on writing journal in the future, we will get so many benefits from this way. Our English will improve especially for writing skill. (P05)

Hanif Maulaniam Sholah

Enhancing EFL Learners' Writing Skill via Journal Writing
(112)

http://e-journal.ikhac.ac.id/index.php/alsuna https://doi.org/10.31538/alsuna 


\section{Conclusion}

The investigation of the use of journal writing as an extensive activity to trigger learners' writing motivation and enhance their writing skill as well as to establish a close relationship between teachers and learners have many benefits. Based on the result of the data analyzed in this research, it can be concluded that the implementation of journal diary in the teaching and learning process of writing is believed to be an effective way to improve the students' writing skills.

By writing journal diary, students can learn many language components autonomously. When they write, they study many vocabularies, try to find many interesting ideas, think how to express their idea and memorize sentence structure as well as grammar. As shown on the interview between students and researcher, students show better understanding about recount text and the process on how to write recount text. In addition, the progress of writing on week by week was getting better. They can reduce the mistakes that they have made before. The improvement on the diary they submitted to the teacher is not only on the length of paragraph, a number of words and grammar, but also on the term of paragraph organization, language use, and mechanic. Through students' journal diaries, teachers are able to measure each student' competence and recognize their needs, thoughts, and feelings, which helps teachers provide learners' preferences toward teaching method and technique which is appropriate with the learners.

In terms of quantitative data, it described the improvement on the students' writing skills which could be seen from the results of the studentse writing scores and students questionnaires. The scores of students on every journal diary they submitted each week increase to some points. Furthermore, The result of questionnaires show that $80 \%$ students respond positively to the journey of journal diary.

Hanif Maulaniam Sholah

Enhancing EFL Learners’ Writing Skill via Journal Writing

$$
\begin{array}{r}
\text { ALSUNA Vol. 2 (2), } 2019 \\
\hline \text { http://e-journal.ikhac.ac.id/index.php/alsuna } \\
\text { https://doi.org/10.31538/alsuna }
\end{array}
$$


By having students' journal, teacher can understand students' problem related with English learning which give overview to the teacher on how to accommodate appropriate assistance for the students to solve their problems.

\section{Bibliography}

Amalia, Eka Rizki. “Developing English Textbook Material for Islamic Primary Education Program: A Participatory Action Research." ALSUNA: Journal of Arabic and English Language, vol. 1, no. 2, 2018, pp. 69-77.

Byrne, D. Teaching Writing Skills. Longman, 1991.

Chanderasegaran, A. "Intervening to Help in the Writing Process." RELC Portfolio Series $7,2002$.

Fegerson, L., and M. L. Nickerson. All in One. Marie Louse Prentice Hall, 1992.

Hamp-Lyons, L., and B. Heasly. Study Writing. 2nd ed., Cambridge University Press, 2006. Harmer, J. The Practice of English Language Teaching. 4th ed., Pearson Education, 2007.

Hedge, T. Writing. Oxford University Press, 1991.

Lagan, J. College Writing Skills. Longman, 2000.

Larsen-Freeman, D. Technique and Principles in Language Teaching. Oxford American English, 2003.

Ngoh, T. .. "From Journals to Weekly Papers." Guidelines, vol. 24, 2002.

Nunan, D. Second English Teaching and Learning. Heinle Publishers, 1999.

Skehan, P. "A Framework for The Implementation of Task-Based Instruction." Applied Linguistics, vol. 17, no. 1, 1996, pp. 38-61.

Spaventa, S. Essay Writing. Cambridge. Cambridge University Press, 2000.

Hanif Maulaniam Sholah

Enhancing EFL Learners' Writing Skill via Journal Writing

$$
\begin{array}{r}
\text { ALSUNA Vol. 2 (2), } 2019 \\
\hline \hline \text { http://e-journal.ikhac.ac.id/index.php/alsuna } \\
\text { https:/ /doi.org/10.31538/alsuna }
\end{array}
$$


Tho, L. N. .. A Survey of Writing Problems of USSH First-Year Students of English. Ho Chi Minh City, 2000.

Tin, T. .. Creative Writing in EFL/ESL Classrooms. Universiti Putra Malaysia Press, 2004.

Weir, C. .. Communicative Language Teaching. GB: Prentice Hall International, 1990.

White, R., and V. Arndt. Process Writing. Longman, 1991.

Zuana, Muhammad Mujtaba Mitra. “Digital Storytelling: An Attractive Media to Teach Narrative Text in Speaking Class." ALSUNA: Journal of Arabic and English Language, vol. 1, no. 1, 2018, pp. 26-39.

\section{Data Attachments}

\section{Table 1. Descriptive statistics for writing fluency}

\begin{tabular}{|c|c|c|c|c|c|}
\hline \multirow[t]{2}{*}{ Groups } & \multirow[t]{2}{*}{ Items } & \multicolumn{2}{|l|}{ Test } & \multicolumn{2}{|c|}{ Changes } \\
\hline & & Pretest & Posttest & Value & Percentage \\
\hline CG & $\begin{array}{l}\text { Average number } \\
\text { of words per } \\
\text { essay }\end{array}$ & 195.21 & 203.11 & 7.90 & $3.89 \%$ \\
\hline EG & $\begin{array}{l}\text { Average number } \\
\text { of words per } \\
\text { essay }\end{array}$ & 194.20 & 213 & 18.80 & $9.80 \%$ \\
\hline $\begin{array}{l}\text { Difference } \\
\text { between EG and } \\
\text { CG }\end{array}$ & $\begin{array}{l}\text { Average number } \\
\text { of words per } \\
\text { essay }\end{array}$ & 1.01 & -9.89 & 8.88 & - \\
\hline
\end{tabular}

Table 2. Descriptive statistics for writing accuracy

\begin{tabular}{|c|c|c|c|c|c|}
\hline \multirow[t]{2}{*}{ Groups } & \multirow[t]{2}{*}{ Items } & \multicolumn{2}{|l|}{ Test } & \multicolumn{2}{|c|}{ Changes } \\
\hline & & Pretest & Posttest & Value & Percentage \\
\hline CG & $\begin{array}{l}\text { Average number of mistakes per } \\
\text { essay }\end{array}$ & 22.56 & 15.88 & 6.68 & $30.2 \%$ \\
\hline EG & $\begin{array}{l}\text { Average number of mistakes per } \\
\text { essay }\end{array}$ & 23.00 & 8.12 & 14.88 & $60.80 \%$ \\
\hline $\begin{array}{l}\text { Difference } \\
\text { between EG and } \\
\text { CG }\end{array}$ & $\begin{array}{l}\text { Average number of mistakes per } \\
\text { essay }\end{array}$ & 1.56 & 7.76 & 6.20 & - \\
\hline
\end{tabular}

Hanif Maulaniam Sholah

Enhancing EFL Learners' Writing Skill via Journal Writing
(115)

ALSUNA Vol. 2 (2), 2019 http://e-journal.ikhac.ac.id/index.php/alsuna https://doi.org/10.31538/alsuna 


\section{Table 3. Descriptive statistics for writing scores}

\begin{tabular}{|l|l|l|l|l|l|}
\hline \multicolumn{2}{l}{ Groups } & Items & Test & \multicolumn{3}{l|}{ Changes } \\
\cline { 3 - 6 } & & Pretest & Posttest & Value & Percentage \\
\hline CG & Average scores & 6.30 & 6.76 & 0.46 & $7.3 \%$ \\
\hline EG & Average scores & 6.20 & 7.56 & 1.36 & $21.9 \%$ \\
\hline Difference between EG and & Average scores & 0.10 & 0.8 & 0.9 & - \\
\hline CG & & & & & \\
\hline
\end{tabular}

Table 4. Descriptive statistics for EG learners' writing motivation questionnaire survey

\begin{tabular}{|c|c|c|c|c|}
\hline \multirow[t]{2}{*}{ No } & \multirow[t]{2}{*}{ Questions } & \multicolumn{3}{|l|}{ Answers } \\
\hline & & Option & Number of students & Percentage \\
\hline \multirow[t]{2}{*}{1} & \multirow[t]{2}{*}{ Do you like writing journals diary? } & Yes & 21 & $70 \%$ \\
\hline & & No & 9 & $30 \%$ \\
\hline \multirow[t]{2}{*}{2} & \multirow{2}{*}{$\begin{array}{l}\text { Do you think writing journal diary } \\
\text { useful for you? }\end{array}$} & Yes & 22 & $74 \%$ \\
\hline & & No & 8 & $26 \%$ \\
\hline \multirow[t]{3}{*}{3} & \multirow[t]{3}{*}{$\begin{array}{l}\text { How much time do you spend } \\
\text { writing journal diary in a day? }\end{array}$} & $\begin{array}{l}\text { Approximately an } \\
\text { hour }\end{array}$ & 11 & $36 \%$ \\
\hline & & $\begin{array}{l}\text { Approximately half } \\
\text { an hour }\end{array}$ & 13 & $44 \%$ \\
\hline & & Less than 25 minutes & 6 & $20 \%$ \\
\hline \multirow[t]{2}{*}{4} & \multirow[t]{2}{*}{$\begin{array}{l}\text { When writing journal diary or } \\
\text { doing any other English learning } \\
\text { activities, do you often think }\end{array}$} & $\begin{array}{l}\text { In Indonesian } \\
\text { language first and } \\
\text { then translate into } \\
\text { English? }\end{array}$ & 24 & $80 \%$ \\
\hline & & In English directly & 6 & $20 \%$ \\
\hline \multirow[t]{2}{*}{5} & \multirow{2}{*}{$\begin{array}{l}\text { Will you keep continuing writing } \\
\text { journal diary in the future? }\end{array}$} & Yes & 25 & $83 \%$ \\
\hline & & No & 5 & 17 \\
\hline
\end{tabular}

Hanif Maulaniam Sholah

Enhancing EFL Learners' Writing Skill via Journal Writing
(116)

ALSUNA Vol. 2 (2), 2019

http://e-journal.ikhac.ac.id/index.php/alsuna https://doi.org/10.31538/alsuna 